\title{
ICTs in the Classroom, Multiliteracy and Special Education: A Required Interface
}

\author{
Ana Lúcia Manrique1, Eliana Vianna Brito Kozma2 , Ely Antonio Tadeu Dirani3, \\ Meire Luci da Silva4 ${ }^{4}$ Annie France Frere ${ }^{5}$ \\ ${ }^{1}$ Mathematics Education Program, PUC-SP, São Paulo, Brazil \\ ${ }^{2}$ Master Degree in Applied Linguistics, UNITAU, São Paulo, Brazil \\ ${ }^{3}$ Department of Engineering, PUC-SP, São Paulo, Brazil \\ ${ }^{4}$ Department of Physical Therapy and Occupational Therapy, UNESP, São Paulo, Brazil \\ ${ }^{5}$ Department of Engineering, UBC, São Paulo, Brazil \\ Email: analuciamanrique@gmail.com,evbrito@uol.com.br,elydirani@gmail.com, \\ meire@marilia.unesp.br, af.slaets@uol.com.br
}

Received 1 April 2016; accepted 21 May 2016; published 24 May 2016

Copyright (C) 2016 by authors and Scientific Research Publishing Inc.

This work is licensed under the Creative Commons Attribution International License (CC BY). http://creativecommons.org/licenses/by/4.0/

(c) (i) Open Access

\begin{abstract}
Many children have special difficulties to interact with their counterparts, but use tablets and smartphones with resourcefulness. Cards with graphic symbols are very useful to assist communication. However, the teacher who works in a classroom with forty students in Brazil does not have time to train the special student to properly use this alternative means of communication. Therefore, this research developed and tested an application installed on a smartphone, which identified the communication card and verbalized its meaning, repeating this action as often as necessary without teacher intervention. It also allows one to test the knowledge of students. The system is based on a web application with source code developed by Google and electromagnetic sensors fixed on the cards. The functionality test showed good performance and usability and may be useful in the training of children with communication difficulties.
\end{abstract}

\section{Keywords}

ICT, Multiliteracy, Special Education, PECS, Autism Spectrum Disorder

\section{Introduction}

Since the development of the Global Information Network, World Wide Web, society is faced with a multitude of terms such as cyberspace, information and communications technology (ICT), hypertext, hypermedia, multi- 
literacy, among others. They represent not only a technological breakthrough, but also a fundamentally new way of apprehending reality. Increasingly digital, our daily life is no longer what it was forty years ago when we had to wait for newspapers on the next day to know what happened the day before. As Rojo (2013: p. 8), states, "if contemporary texts have changed, competences or reading skills and production of texts required to participate in current literacy practices cannot be the same". However, in the case of the school context, these concepts are not always properly understood. We barely begun to understand the difference between reading acquisition and literacy, and now there is the concept of multiliteracy, i.e., the ability of the user to read and produce texts in different media, including digital media.

In the case of the Brazilian educational scenario, we know that the school cannot be distanced from this multimedia reality. Teachers need to know and, why not say, dominate the technological resources that are increasingly becoming more sophisticated, so that their classes correspond to the expectations and the student needs, regardless of the type of education or level of education.

Such considerations lead us to reflect on the relation between the use of technology and the process of multiliteracy development in Special Education. According to the Article 58 of the Brazilian Law of Guidelines and Bases of National Education (Brazil, 2013), Special Education is a type of education preferably offered in the regular school system for students with disabilities, global developmental disorders, high-skill students or gifted students.

The inclusive education policy, developed by the Ministry of Education of Brazil, has organizing guidelines and actions of Specialized Educational Services offered to students with disabilities as primary objective of not only substituting the regular teaching, but also complementing their formation (Dutra, 2007).

Several studies have addressed with particular interest the issue relating to Special Education. Among them, it can be mentioned the articles by Carneiro, Dall'Acqua and Caramori (2015), and Passerino and Santarosa (2008), which investigate teaching practices in inclusive classrooms and multi-functional resources in classrooms.

About the use of digital technologies Msila (2015) sought to explore the teachers' opinions and found that while many teachers have disposition and good will towards innovations in education, the Information and Communication Technologies-ICTs may expose of their limitations in the classroom. The findings show that the success of digital technology in the classroom depends on the competence of the teacher and on their positive attitudes in using ICTs.

As pointed out, the admission of a child with special needs in a regular school is a right guaranteed by law. The school in turn must provide the effective integration of the student to life in society. However, what is observed in Brazil is that many educational institutions adopt actions that do not solve the challenge of inclusion (Moreira \& Manrique, 2014). According to Mantoan (2007: p. 45):

"Most schools are still far from becoming inclusive. Generally, there are schools that develop partial inclusion projects, which are not associated with basic changes in these institutions and continue to meet students with disabilities in school semi or fully segregated spaces (special classes, special schools)".

Indeed, the heart of the matter regarding inclusive education lies in that many education professionals (teachers, managers, coordinators) forget that it is not the child who must adapt to the school, but the institution receiving the special student must go through many changes, among them the formation of teachers, their ability to handle digital technologies and their pedagogical approach to engage students in multiple literacies.

Moreover, as often in Brazil, teacher education does not prepare teachers for an inclusive education. Consequently, when they start teaching, they are unprepared to manage and individualize the attention for students with special needs. It may also be said that although digital technologies exert on children a growing attraction inside the school context, the effective use by teachers are still scarce (computers, laptops, tablets, smartphones, which are part the child's universe).

In the case of special children, the situation is not different. Although many children have difficulties to interact face to face with his interlocutors whether at home or in the classroom, they use tablets and smartphones with agility, with great skill. Thus, why not use these technological resources in the classroom for educational purposes?

In the classroom, the teacher and the student establish a teaching-learning relationship. For this relationship to succeed, it is necessary that the school environment be favorable to special students (Beavis, Muspratt, \& Thompson, 2015; Vogel \& Amate, 2014; Meer, Didden, Sutherland, O’Reilly, \& Sigafoos, 2012). Each student must receive a personalized treatment with resources to facilitate his communication with teachers (Mello \& Scanzerla, 2013). 
Several research studies were developed to help nonverbal autistic (Kanner, 1943) people communicate using smartphones to express their feelings and needs (Zhang, 2010). Other researchers developed applications to help students with communication difficulties with their learning inside and outside the classroom (El-Seoud, Samir, Karkar, Ja'Am, \& Karam, 2014; Silva, Prado, Scardovelli, Bochi, Campos, \& Frère, 2014; Scardovelli \& Frere, 2015). One application supports the creation of educational content using the android technology and built-in speaker and camera features (Vullamparthi, Nelaturu, Mallaya, \& Chandrasekhar, 2013; Castro, Bissaco, Panccioni, Rodrigues, \& Domingues, 2014). Other researchers (Niwa, Ishii, \& Torii, 2014) developed a tool to reward the autistic person showing an appropriate behavior. Others developed applications to aid communication with the teacher (Figueroa \& Ramírez, 2014).

In addition to these technological resources, cards with graphic symbols are used to assist communication. These images share common characteristics among themselves and are designed to meet different requirements and needs of users (Conklin \& Mayer, 2011; Farias, Silva, \& Cunha, 2014; Portugal, 2008). The symbolic system called Picture Exchange Communication System (PECS) is one of the most used in the world (Travis \& Geiger, 2010). The PECS system has the following characteristics: it is simple, with a clear design for an easy recognition; it is suitable for users of any age, and easy to be combined with other figures and photos. They are useful for creating educational activities (Figueroa \& Ramírez, 2014; Fernandes, Oliveira, Rodrigues, \& Vita, 2014) and for the communication of the student with the teacher, which requires a differentiated and individualized handling (El-Seoud, Samir, Karkar, Ja’Am, \& Karam, 2014).

However, often the student only acquires this ability performing after many repetitions and with a great effort by a teacher. In Brazil, teachers teach in rooms with 40 students, making it difficult to provide such a particular attention to the student, which may even regress due to the lack of interaction (Brazil, 2008; Brazil, 2012).

We initially presented these considerations so that, from the point of view of Brazilian educational policies, we could elucidate the scope of this work, which focuses on using new technologies to enable alternative means of learning and communication for children with autism or intellectual disabilities.

Therefore, in this study, we developed an application installed on a smartphone that identifies the communication card and verbalizes its meaning. It also tests learning in a dynamic and interactive way, and rewards successes through applause or points. We thus intend to help the teacher to propose tasks that the student is able to execute without any help, to repeat the exercises until scoring and to test student's knowledge.

The method uses a smartphone because this is a resource by which teachers, even those less familiar with ICTS, do not feel intimidated.

\section{Method}

For this research, which aims to help the training of autistic students and students with intellectual difficulties in identifying communication cards, we use an application installed on a smartphone. The application allows choosing between PECS or cards used in school. We used PECS because they decreased problem behaviors and increased speech in some individuals (Banda \& Hart, 2010; Ganz, Heath, Rispoli, \& Vollrath, 2010). And they were developed to teach functional communication to children with limited speech (Bondy \& Frost, 2001; Malone, Fant, \& Tullis, 2010; Greenberg, Tomaino, \& Charlop, 2012).

The program is divided into two stages. The first stage is intended for training the identification of communication cards. At this stage, students choose a card and place it next to the smartphone. The system verbalizes the action represented in the card. The student may repeat the procedure with the same card or other cards, according to what was planned by the teacher in relation to the difficulties of the student.

In the second phase, when the teacher considers that the learning achieved its objective, the test program is triggered. The system vocalizes one the actions selected by the teacher. The student must choose the corresponding card and place it next to the smartphone. The system emits applause sounds when the student scores or asks to try again if it failed.

\section{Materials}

As materials, we used Near Field Communication-NFC tags and a smartphone able to read these tags. The NFC (ISO/IEC, 2013) is the latest wireless technology. Communication occurs when this tag is a few centimeters from the smartphone. This data transmission method is based on RFID using electromagnetic fields to enable communication between electronic devices.

The technology uses a $13.56 \mathrm{MHz}$ frequency, with a $2 \mathrm{MHz}$ bandwidth, amplitude-shift keying (ASK) and 
biphasic level coding. It supports data rates of 106.212 - $424 \mathrm{Kbit} / \mathrm{s}$. The tag has two models of communication: passive and active. The antenna of an active reader (smartphone) generates an electromagnetic field that, by approximation, activates the passive tags. It can store up to $4 \mathrm{~KB}$. Active tags have their own power supply.

For this work, we used 128-byte passive tags, enough space to store a 13-digit code with the identification of an object and its description.

The software was developed using the MIT App Inventor 2 (MIT, 2014). This interface is an open source web application developed by Google and maintained by the Massachusetts Institute of Technology. The interface is divided into two parts, one conceived for the dedicated application design and another for logic operations. The program is based on Scheme and the result is an application for the Android system. Google developed the voice system.

\section{Results}

We selected six PECS communication cards to put NFC tag on the upper left corner of a set of basic PECS cards (Figure 1). The PECS figures used in this paper are extracted from the site http://caminhosdoautismo.blogspot.com.br/2010/06/especial-pecs-sistema-de-comunicacao.html. The 6 PECS communication cards have been tested by the system. We fixed an NFC tag in the upper left corner of each card (Figure 2). The phone was placed in the upper compartment of an MDF box $20 \times 20 \times 2 \mathrm{~cm}$ with an internal division.

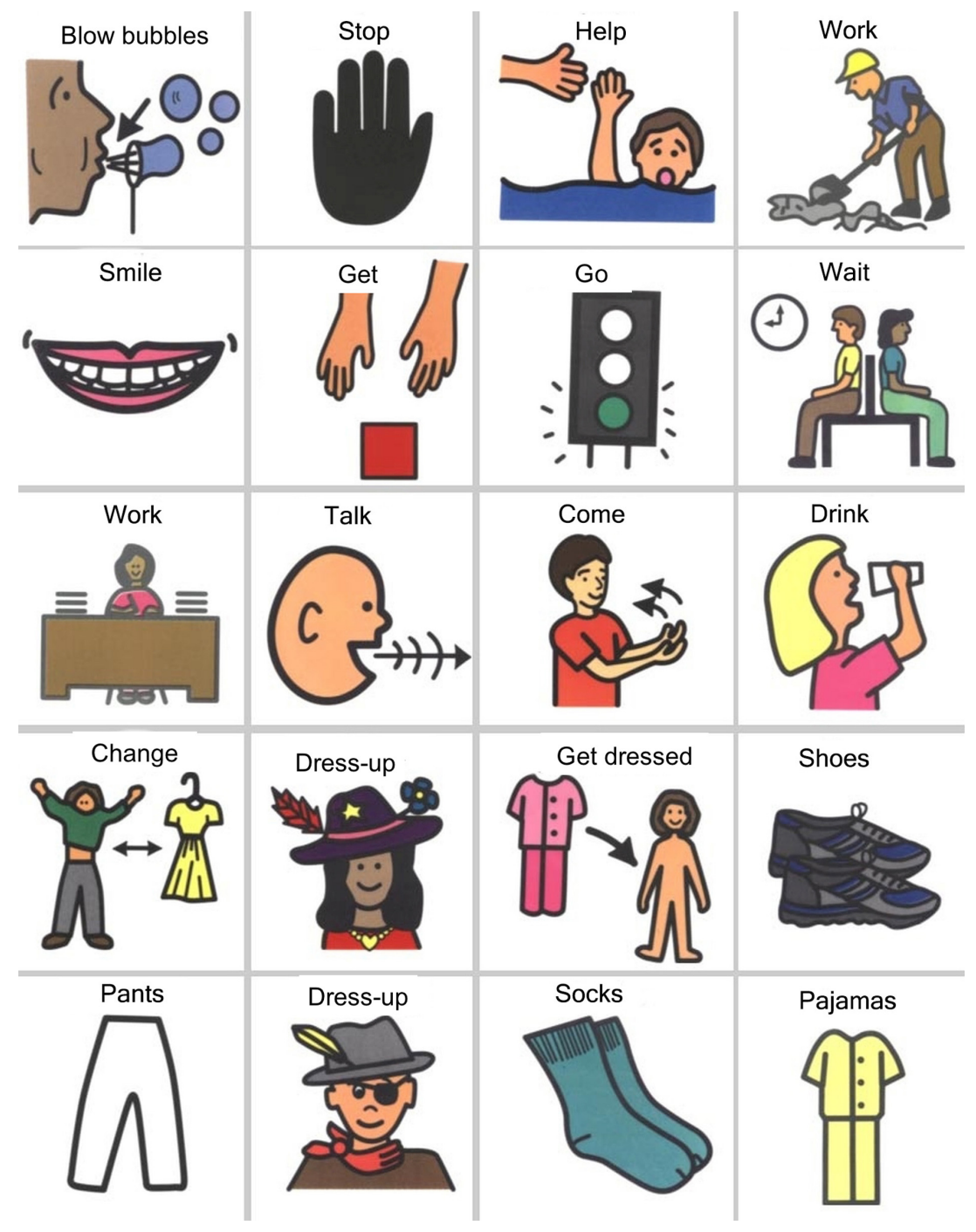

Figure 1. Examples of PECS cards. 
We accommodated the communication cards in a MDF auxiliary box located $10 \mathrm{~cm}$ from the main box. It is worth mentioning that, if we put the cards that are not being tested, at a distance of $10 \mathrm{~cm}$ from the card to be identified, the system has no interference.

For the first phase test, we put one of the cards in the lower compartment of the main box. If the NFC tag number, identified at reading, is on the phone database, the system plays an audio message describing the card. The procedure was repeated 10 times with each card.

For the second phase test, we verified whether the system prompts the selection of each of the cards and identifies whether the chosen card matches or not what was verbalized. There were 10 right choices and 10 wrong choices.

And Table 1 shows examples of right and wrong choices and verbalized responses.

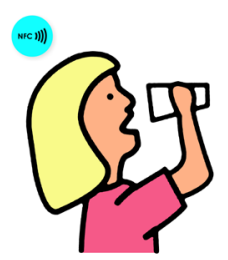

Figure 2. Example of the card with NFC tag.

Table 1. Examples of right and wrong choices and verbalized responses.

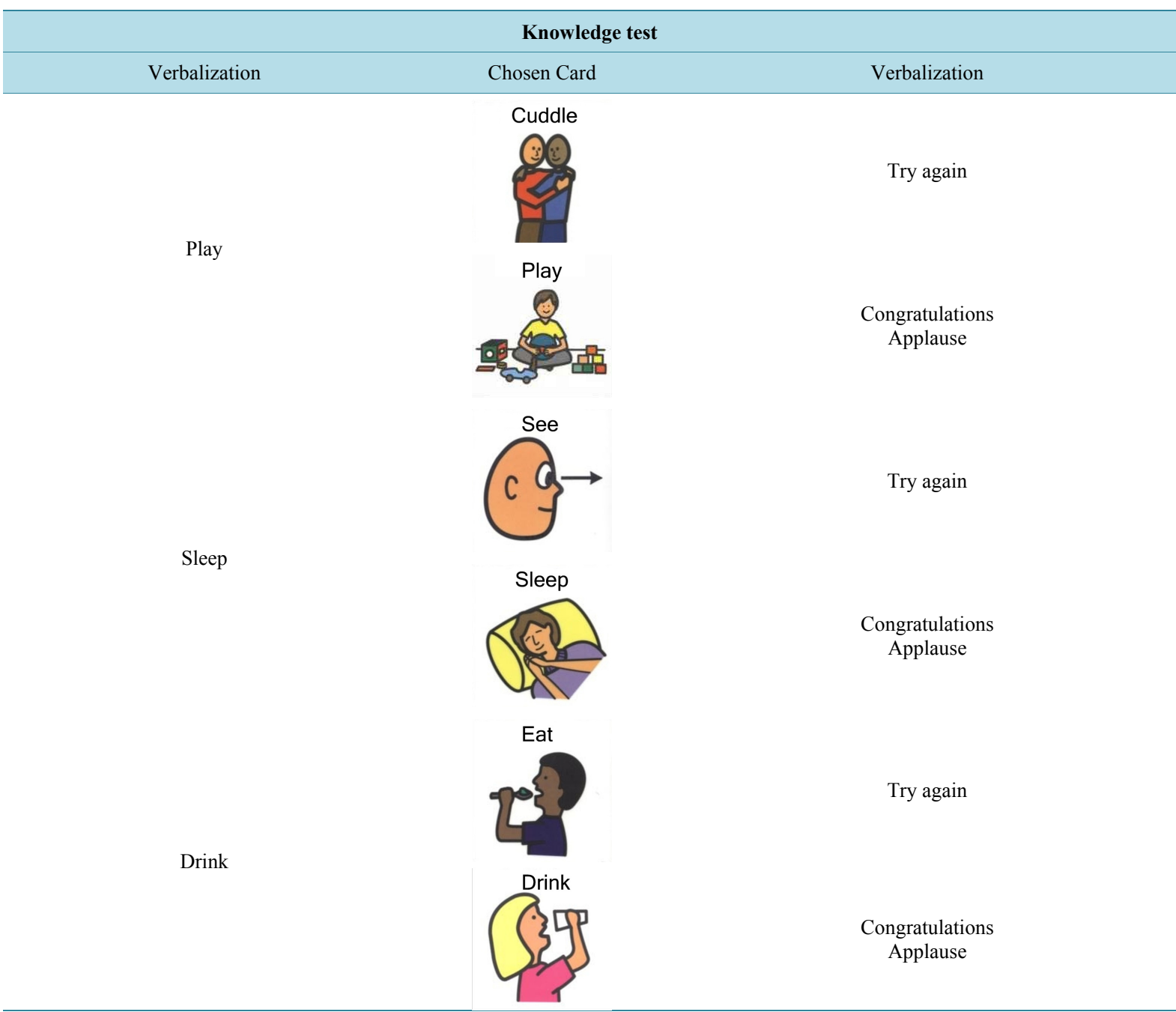


Each PECS card was repeated 10 times without any identification error (if only one card was selected at a time) to test the first phase. In second phase tests, no failures were identified.

The verbalization is made with a feminine, clear voice, without noise and with a good pronunciation.

\section{Conclusion}

In this work, we developed a system to help students with communication difficulties to train the understanding of communication cards. We consider works as Heimann, Nelson, Tjus, \& Gillberg (1995); Dautenhahn \& Billard (2002); Naha, Roy, Ahmed, Samrose, \& Rahman (2011); Kagohara, Meer, Ramdoss, O’reilly, Lancioni, Davis et al. (2013); Marcu, Tassini, Carlson, Goodwyn, Rivkin, Schaefer et al. (2013) and Desai, Chow, Mumford, Hotze, \& Chau (2014), who claim that some technologies can be designed for engaging children in imitative interactive games.

We used a smartphone to develop the system because it is a device known by most teachers. Thus, a rejection to technological innovation is unlikely to occur, since it does not expose the inability of teachers in relation to digital technology. In addition, smartphones also attract the attention of children. Mintz (2013) claims that some children with autism spectrum disorder-ASD have preferred to receive persuasive messages from mobile devices. However, the literature indicates that there is a lack of published studies on the use of mobile technology for children with ASD (Yee, 2012).

The system showed a good performance and was easy to use. However, it was not tested with children with communication difficulties. It was also limited to requesting, identifying and verbalizing the meaning of a chosen card, and identifying scores and fails aiming only to help the training in identifying communication cards. The system is easy to be programmed, allowing other applications to reward correct answers (scores) using only sounds of applause. However, we are already developing a game to encourage learning more.

Ramdoss, Machalicek, Mulloy, Lang, \& O'reilly (2012) elaborated a systematic review about Computer-based interventions-CBI to improve social and emotional skills in individuals with autism spectrum disorders. The study suggests that the use of CBI to improve the social and emotional skills of individuals with ASD is a promising practice. In this sense, the application that we developed may help special children to communicate and thus to reduce their stress and anxiety.

\section{Acknowledgements}

The authors thank the CNPq for their financial support.

\section{References}

Banda, D., \& Hart, L. (2010). Picture Exchange Communication System with Individuals with Developmental Disabilities: A Meta-Analysis of Single Subject Studies. Remedial and Special Education, 31, 476-488. http://dx.doi.org/10.1177/0741932509338354

Beavis, C., Muspratt, S., \& Thompson, R. (2015). Computer Games Can Get Your Brain Working: Student Experience and Perceptions of Digital Games in the Classroom. Learning, Media and Technology, 40, 21-42. http://dx.doi.org/10.1080/17439884.2014.904339

Bondy, A., \& Frost, L. (2001). The Picture Exchange Communication System. Behavior Modification, 25, 725-744. http://dx.doi.org/10.1177/0145445501255004

Brazil. (2008). Decreto n. 6.571 Atendimento Educacional Especializado. From Secretaria de Educação Especial: http://portal.mec.gov.br/index.php?option=com_content\&view=article\&id=288\&Itemid=355

Brazil. (2012). O Autista para os efeitos da Lei n. 12.764, 27/12/2012. Retrieved 9 de 2013 from Presidência da República: http://www.planalto.gov.br/ccivil 03/ ato2011-2014/2012/lei/112764.htm

Brazil. (2013). Lei de Diretrizes e Bases da Educação Básica n. 12.796. Retrieved 2 de 2016 from MEC: www.planalto.gov.br

Carneiro, R., Dall'Acqua, M., \& Caramori, P. (2015). School Inclusion and Classroom Management: Challenges and Possibilities. Creative Education, 6, 2037-2044. http://dx.doi.org/10.4236/ce.2015.619209

Castro, M., Bissaco, M., Panccioni, B., Rodrigues, S., \& Domingues, A. (2014). Effect of a Virtual Environment on the Development of Mathematical Skills in Children with Dyscalculia. PLos One, 9, 1-15.

http://dx.doi.org/10.1371/journal.pone.0103354

Conklin, G., \& Mayer, R. (2011). Effects of Implementing the Picture Exchange Communication System (PECS) with 
Adults with Developmental Disabilities and Severe Communication Deficits. Remedial and Special Education, 32, 155166. http://dx.doi.org/10.1177/0741932510361268

Dautenhahn, K., \& Billard, A. (2002). Games Children with Autism Can Play with Robota, a Humanoid Robotic Doll. In S. Keates, P. Langdon, P. Clarkson, \& P. Robinson c Universal Access and Assistive Technology (pp. 179-190). London, UK: Springer-Verlag. http://dx.doi.org/10.1007/978-1-4471-3719-1_18

Desai, T., Chow, K., Mumford, L., Hotze, F., \& Chau, T. (2014). Implementing an iPad-Based Alternative Communication Device for a Student with Cerebral Palsy and Autism in the Classroom. Computers \& Education, 79, 148-158. http://dx.doi.org/10.1016/j.compedu.2014.07.009

Dutra, C. (2007). Prefácio. In E. Fávero, L. Pantoja, \& M. Mantoan (Eds.), Atendimento Educacional Especializado: Aspectos Legais e Orientação Pedagógica (p. 5). São Paulo: MEC/SEESP.

El-Seoud, M., Samir, A., Karkar, A., Ja’Am, J. M., \& Karam, O. H. (2014). A Pictorial Mobile-Based Communication Application for Non-Verbal People with Autism. 2014 International Conference on Interactive Collaborative Learning (ICL), Dubai, 2014, 529-534.

Farias, E., Silva, L., \& Cunha, M. (2014). ABC AUTISMO: Um aplicativo móvel para auxiliar na alfabetização de crianças com autismo baseado no Programa TEACCH. X Simpósio Brasileiro de Sistemas de Informação (pp. 458-469). LondrinaPR: SBSI.

Fernandes, F., Oliveira, L., Rodrigues, M., \& Vita, S. (2014). Realidade aumentada aplicada na alfabetização de crianças autistas por meio de dispositivos móveis. XXIV Congresso Brasileiro de Engenharia Biomédica (pp. 33-36). UberlândiaMG: SBEB.

Figueroa, A., \& Ramírez, R. (2014). Orchestrating Assistive Technology: Enabling Autistic People to Communicate with Others. IEEE International Conference on Consumer Electronics, Las Vegas, 10-13 January 2014, 234-235.

Ganz, J. B., Heath, A. K., Rispoli, M. J., \& Vollrath, T. L. (2010). Impact of AAC versus Verbal Modeling on Verbal Imitation, Picture Discrimination, and Related Speech: A Pilot Investigation. Journal of Developmental and Physical Disabilities, 22, 179-196. http://dx.doi.org/10.1007/s10882-009-9176-2

Greenberg, A. L., Tomaino, M. A., \& Charlop, M. H. (2012). Assessing Generalization of the Picture Exchange Communication System in Children with Autism. Journal of Developmental and Physical Disabilities, 24, 539-558. http://dx.doi.org/10.1007/s10882-012-9288-y

Heimann, M., Nelson, K. E., Tjus, T., \& Gillberg, C. (1995). Increasing Reading and Communication Skills in Children with Autism through an Interactive. Journal of Autism and Developmental Disorders, 25, 459-480. http://dx.doi.org/10.1007/BF02178294

ISO/IEC (2013). ISO/IEC 18092:2013. Information Technology—Telecommunications and Information Exchange between Systems - Near Field Communication - Interface and Protocol (NFCIP-1).

http://www.iso.org/iso/home/store/catalogue ics/catalogue_detail_ics.htm?csnumber $=56692$

Kagohara, D. M., Meer, L. V., Ramdoss, S., O’Reilly, M. F., Lancioni, G. E., Davis, T. N. et al. (2013). Using iPods ${ }^{\circledR}$ and $\mathrm{iPads}^{\circledR}$ in Teaching Programs for Individuals with Developmental Disabilities: A Systematic Review. Research in Developmental Disabilities, 34, 147-156. http://dx.doi.org/10.1016/j.ridd.2012.07.027

Kanner, L. (1943). Autistic Disturbance of Affective Contact. Nervous Child, 2, 217-250. http://simonsfoundation.s3.amazonaws.com/share/071207-leo-kanner-autistic-affective-contact.pdf

Malone, H. I., Fant, J. L., \& Tullis, C. A. (2010). Using the Picture Exchange Communication System to Increase the Social Communication of Two Individuals with Severe Developmental Disabilities. Journal of Developmental and Physical Disabilities, 22, 149-163. http://dx.doi.org/10.1007/s10882-009-9174-4

Mantoan, M. (2007). Educação Inclusiva: Orientações pedagógicas. In E. Fávero, \& L. Pantoja (Eds.), Atendimento Educacional Especializado: Aspectos Legais e Orientação Pedagógica (pp. 45-60). São Paulo: MEC/SEESP.

Marcu, G., Tassini, K., Carlson, Q., Goodwyn, J., Rivkin, G., Schaefer, K. J. et al. (2013). Why Do They Still Use Paper? Understanding Data Collection and Use in Autism Education. Proceedings of the SIGCHI Conference on Human Factors in Computing Systems, Paris, 27 April-2 May 2013, 3177-3186.

Meer, L. V., Didden, R., Sutherland, D., O’Reilly, M. F., E., L. G., \& Sigafoos, J. (2012). Comparing Three Augmentative and Alternative Communication Modes for Children with Developmental Disabilities. Journal of Developmental and Physical Disabilities, 24, 451-468. http://dx.doi.org/10.1007/s10882-012-9283-3

Mello, C., \& Scanzerla, M. (2013). Aplicativo Android para auxiliar no desenvolvimento da comunicação de Autistas. XVIII Congresso Internacional de Informática Educativa, PUC-RS, Porto Alegre, 231-239.

Mintz, J. (2013). Additional Key Factors Mediating the Use of a Mobile Technology Tool Designed to Develop Social and Life Skills in Children with Autism Spectrum Disorders: Evaluation of the 2nd HANDS Prototype. Computers \& Education, 63, 17-27. http://dx.doi.org/10.1016/j.compedu.2012.11.006 
MIT (2014). Acesso em 3 de 2016, disponível em MIT App Inventor. http://appinventor.mit.edu/explore/tutorial-version/app-inventor-2.html

Moreira, G., \& Manrique, A. (2014). Challenges in Inclusive Mathematics Education: Representations by Professionals Who Teach Mathematics to Students with Disabilities. Creative Education, 5, 470-483. http://dx.doi.org/10.4236/ce.2014.57056

Msila, V. (2015). Teacher Readiness and Information and Communications Technology (ICT) Use in Classrooms: A South African Case Study. Creative Education, 6, 1973-1981. http://dx.doi.org/10.4236/ce.2015.618202

Naha, N. R., Roy, P. C., Ahmed, I., Samrose, S., \& Rahman, M. M. (2011). A-Class: A Classroom Software with the Support for Diversity in Aptitudes of Autistic Children. IEEE Symposium on Computers \& Informatics (ISCI), Kuala Lumpur, 20-23 March 2011, 727-731.

Niwa, T., Ishii, N., \& Torii, I. (2014). Development of Smart Devices Applications for Autistic Children. IIAI 3rd International Conference on Advanced Applied Informatics (IIAIAAI), Kitakyushu, 31 August-4 September 2014, 913-918. http://dx.doi.org/10.1109/iiai-aai.2014.180

Passerino, L., \& Santarosa, L. (2008). Autism and Digital Learning Environments: Processes of Interaction and Mediation. Computers \& Education, 51, 385-402. http://dx.doi.org/10.1016/j.compedu.2007.05.015

Portugal (2008). Unidades de Ensino Estruturado para alunos com perturbações de espectro do autismo. Lisboa: Direcção-Geral de Inovação e de Desenvolvimento Curricular , Direcção de Serviços da Educação Especial e do Apoio Sócio-Educativo.

Ramdoss, S., Machalicek, W. M. R., Mulloy, A., Lang, R., \& O’Reilly, M. (2012). Computer-Based Interventions to Improve Social and Emotional Skills in Individuals with Autism Spectrum Disorders: A Systematic Review. Developmental Neurorehabilitation, 15, 119-135. http://dx.doi.org/10.3109/17518423.2011.651655

Rojo, R. (2013).Escol@ conectada: Os multiletramentos e as TICs. São Paulo: Parábola.

Scardovelli, T., \& Frere, A. (2015). The Design and Evaluation of a Peripheral Device for Use with a Computer Game Intended for Children with Motor Disabilities. Computers Methods and Program in Biomedicine, 118, 44-58. http://dx.doi.org/10.1016/j.cmpb.2014.10.002

Silva, A., Prado, S., Scardovelli, T., Bochi, S., Campos, L., \& Frère, A. (2014). Measurement of the Effect of Physical Exercise on the Concentration of Individuals with ADHD. PLOS ONE, 10, e0122119.

Travis, J., \& Geiger, M. (2010). The Effectiveness of the Picture Exchange Communication System (PECS) for Children with Autism Spectrum Disorder (ASD): A South African Pilot Study. Child Language Teaching \& Therapy, 26, 39-59. http://dx.doi.org/10.1177/0265659009349971

Vogel, D., \& Amate, F. (2014). Development of a Game for the Evaluation of Operative Structure in Teenagers with Down Syndrome. Journal of Accessibility and Design for All, 4, 1-12.

Vullamparthi, A., Nelaturu, S., Mallaya, D., \& Chandrasekhar, S. (2013). Assistive Learning for Children with Autism Using Augmented Reality. IEEE 5th International Conference on Technology for Education (T4E), Kharagpur, 18-20 December 2013, 43-46. http://dx.doi.org/10.1109/t4e.2013.18

Yee, H. (2011). Mobile Technology for Children with Autism Spectrum Disorder: Major Trends and Issues. IEEE Symposium on E-Learning, E-Management and E-Services (IS3e), Kuala Lumpur, 21-24 October 2012, 1-5.

Zhang, L. (2010). Affect Sensing in an Affective Interactive E-Theatre for Autistic Children. International Conference on Natural Language Processing and Knowledge Engineering (NLP-KE), Beijing, 21-23 August 2010, 1-8. http://dx.doi.org/10.1109/nlpke.2010.5587813 